\title{
Migration settlement networks in the Carpathian Basin, 2001-2011
}

\author{
Áron Kincses Looking at the relationship between the place of \\ Hungarian Central birth and current residential locations of foreign \\ Statistical Office, citizens arriving in Hungary from the neighbouring \\ Budapest, Hungary countries, in general, we establish that smaller \\ E-mail: migration distance involves migrants with a lower \\ aron.kincses@ksh.hu level of education, while preference for longer \\ distances is determined by higher qualifications of \\ migrants. The potential impact area of migrants \\ Lajos Bálint grows in line with the education attainments of \\ Hungarian Demographic migrants. \\ Research Institute A scale-free settlement topology can be seen \\ Budapest, Hungary from the neighbouring countries of immigration to \\ E-mail: Hungary. This means that most of the settlements \\ balint@demografia.hu of Hungary have just a few links to settlements of \\ neighbouring countries, from a migration point of \\ view, while few Hungarian settlements have many \\ connections. This finding also means that, instead of \\ Keywords: the national migration strategy, the subsidiary and \\ international migration, the regional strategies can play a decisive role in the \\ Carpathian Basin, management of the international migration process. \\ network analysis
}

\section{Introduction}

The key to migration settlement networks is linking the source countries to the destination areas.

The analysis is based on the data on foreign nationals that is collected from the census and the Office of Immigration and Nationality. Establishing the linkage between the two databases has created an opportunity to connect the study on migration settlements with the detailed information material of the census on the subject.

In this study, we strive to show in detail the characteristics of the international migrants' settlement network in relation to Hungary and its neighbouring countries and connect them to the attributes of migrants.

Analysing the relationship between the Carpathian Basin migration source and destination areas, our aim is not only to explore the regional features of the flows

Regional Statistics, Vol 6, No 2. 2016: 95-113; DOI: 10.15196/RS06205 
between a given emigration country and Hungary but also to depict a general territorial network of contacts in an integrated way, simultaneously taking into account all the neighbouring countries. In this network, which is considered as the specific sub-network of the entire Carpathian Basin network, we will examine the settlement networks of the migrants, mostly of Hungarian ethnicity, arriving to Hungary. The question is whether it is characteristic that some parts of the aforementioned territorial network are increasingly 'utilised' by the foreign citizens living in Hungary and having specific demographic, labour market properties, or given territorial connections are independent of the characteristics of migrants.

\section{Data, relations of source, and destination areas}

Census data represent a detailed demographic, labour market, and sociological data set on the population of migrant origin living in Hungary. However, information on the places of emigration and birth only country is available. Relevant Hungarian migration databases (database of Office of Immigration and Nationality and the HCSO data files) contain less information on the characteristics of migrants, but extend to their places of birth. The establishment of link between the two databases enables to connect the analysis on the emigration areas with the detailed census information material. The method is based on the use of a complex conversion key between databases, which assigns the municipalities in foreign places of birth ${ }^{1}$ to the census data files according to the common variables (nationality, residence in Hungary, date of birth, gender, and marital status). Thus, although data on foreign settlements underlying the specific analyses was available, a separate classification became necessary. It is because such classification often contained the denominations of settlements or parts thereof in different languages.

Hereafter, we conduct a detailed examination of the relationship between the place of birth and current residence of foreign citizens coming to Hungary from neighbouring countries at Nomenclature of Territorial Units for Statistics (NUTS3) level$^{2}$, using the 2001 and 2011 census data (Tóth 2013). As for Ukraine, instead of

\footnotetext{
${ }^{1}$ As a first step, the two databases have been connected by all the five variables. With this method, most records could be corresponded to each other. In the second step, the non-connected rows have been unified with the help of four-element keys (citizenship, the settlement of the Hungarian residence, and two-element subsets of all threeelement variable sets). In some remaining (not connecting) cases, we have used the less differentiated level of district instead of the settlement of the Hungarian residence, thus elaborating five and four-element keys with this method. The application of this method resulted in formation of the new, interconnecting database.

2 This territorial classification is available for most countries, with the exception of Serbia and Ukraine. In case of Serbia, the most probable NUTS3 division is applied (For the territorial division of the Serbian Republic, the classification published in the 2011 Statistical Yearbook has been used. For detailed information, see: http://www.media.srbija.gov.rs/medsrp/dokumenti/SGS2011_cyr.pdf), while in Ukraine such a classification does not exist. The 'oblaszt' level is more integrated and the 'rayon' is more detailed than this classification. A more defined division will be applied to Transcarpathia as it has a distinguished role within Ukraine (the vast majority of migrants come from here).
}

Regional Statistics, Vol 6, No 2. 2016: 95-113; DOI: 10.15196/RS06205 
the whole country - due to its large size - only Transcarpathia has been involved in the study since nearly $90 \%$ of Ukrainian migrants arrive from this region.

From the 161 regions established, in this manner significant concentrations can be observed in the matrix of migrations to the 19 Hungarian counties and Budapest. Extracting those region pairs, which contribute to the total turnover and have more than $0.5 \%$ of the total migration, we get a much tighter group than the previous one. Thus, $43 \%$ of migrations are concentrated in $1 \%$ of all the matrix cells $(42 \times 20=840)$ in 2011. This proportion increased by nine percentage points until 2011.

Central Hungary was the most attractive destination for those arriving from the counties of Transylvania in 2011. Nearly, 4\% of all immigrations from Romania to Hungary took place between Harghita county and Budapest, while the share of moves between Mures County and Budapest was 3\%. The border areas were of considerable importance as well, which can be explained partly by the phenomenon of circulation migration (Fercsik R 2008, Elijah S. et al, 2009, Illés S. et al, 2009) and partly by the ease that borders offer to migrants for maintaining a connect with family members staying at home (Rédei M 2007). Intensive flows (Anderson et al, 1999, Baranyi, B. et al. 2004, N. Hansen 1977; Van Geenhuizen, M. et al, 2001) and transnational areas were formed (Melegh, 2011) between the bordering counties. Among them, the most significant movements included North Backa, North Banat-Csongrád $(2,37 \%$ and $1.16 \%$ ) as well as Beregovo and Uzsgorod rayon-Szabolcs-Szatmár-Bereg county $(2.42 \%$ and $1.35 \%)$. During the same period, a population of mostly Hungarian ethnicity came from the large emitting areas to Hungary.

The number of pairs of regions, which are affected by more than $0,5 \%$ by the migrations from neighbouring countries to Hungary showed an increase by 2011 . The spaces of migratory relations increased in Hungary, with remoter parts of the neighbouring countries joining the source areas, thereby increasing the regional role of Trnava, Bratislava, Košice, Nitra districts, and Vienna'. (Estélyi K. et al. 2006). The significance of Budapest and Pest County further strengthened, while the weight of migration of Szabolcs-Szatmár-Bereg county and, to a certain extent, of Csongrád weakened. Generally, in these counties the number of migrants also increased, but not as much as in Central Hungary. By 2011, the migration ratios between Harghita, Mures, and Budapest continued to increase (3.8\% and $4.5 \%$, respectively). Generally, the cross-border relationship levels retreat. Often, those arriving from the proximity of the borders do not migrate to the neighbouring region of Hungary but to Central Hungary, which provides better structural (labour market and income) facilities.

Regional Statistics, Vol 6, No 2. 2016: 95-113; DOI: 10.15196/RS06205 
Table 1

Proportions of major migration flows*, 2001

\begin{tabular}{|c|c|c|c|c|c|c|c|c|}
\hline $\begin{array}{l}\text { Foreign/ } \\
\text { Hungarian } \\
\text { counties }\end{array}$ & $\begin{array}{l}\text { Buda- } \\
\text { pest }\end{array}$ & $\begin{array}{l}\text { Bács- } \\
\text { Kiskun }\end{array}$ & Békés & $\begin{array}{l}\text { Csong- } \\
\text { rád }\end{array}$ & Fejér & $\begin{array}{l}\text { Hajdú- } \\
\text { Bihar }\end{array}$ & Pest & $\begin{array}{c}\text { Sza- } \\
\text { bolcs- } \\
\text { Szatmár- } \\
\text { Bereg }\end{array}$ \\
\hline Bihor & 1.63 & 0.18 & 0.39 & 0.10 & 0.18 & 0.70 & 2.16 & 0.20 \\
\hline Brasov & 1.25 & 0.08 & 0.05 & 0.11 & 0.09 & 0.03 & 0.21 & 0.03 \\
\hline Cluj & 2.55 & 0.14 & 0.19 & 0.18 & 0.50 & 0.35 & 0.74 & 0.20 \\
\hline Covasna & 1.32 & 0.12 & 0.18 & 0.07 & 0.16 & 0.33 & 0.46 & 0.08 \\
\hline Harghita & 3.75 & 0.46 & 0.51 & 0.65 & 0.41 & 0.40 & 2.61 & 0.30 \\
\hline Maramures & 0.92 & 0.06 & 0.05 & 0.06 & 0.12 & 0.05 & 0.43 & 0.09 \\
\hline Mures & 2.77 & 0.44 & 0.47 & 0.65 & 0.29 & 0.32 & 0.91 & 0.22 \\
\hline Salaj & 1.00 & 0.06 & 0.04 & 0.04 & 0.16 & 0.23 & 0.25 & 0.06 \\
\hline Satu Mare & 1.92 & 0.11 & 0.15 & 0.16 & 0.34 & 0.72 & 0.37 & 0.84 \\
\hline Timis & 0.07 & 0.02 & 0.06 & 0.11 & 0.03 & 0.03 & 0.67 & 0.02 \\
\hline Trnava district & 0.51 & 0.00 & 0.02 & 0.02 & 0.00 & 0.02 & 0.12 & 0.03 \\
\hline Berehove rayon & 0.85 & 0.08 & 0.05 & 0.06 & 0.13 & 0.34 & 0.28 & 2.42 \\
\hline Vynohradiv rayon & 0.56 & 0.10 & 0.06 & 0.06 & 0.01 & 0.15 & 0.21 & 0.90 \\
\hline Uzshorod rayon & 0.67 & 0.06 & 0.11 & 0.03 & 0.10 & 0.30 & 0.42 & 1.35 \\
\hline Juznobacki district & 0.79 & 0.36 & 0.10 & 0.85 & 0.08 & 0.02 & 0.08 & 0.02 \\
\hline Severnobacki district & 0.71 & 0.50 & 0.30 & 2.37 & 0.11 & 0.05 & 0.12 & 0.01 \\
\hline $\begin{array}{l}\text { Severnobanatski } \\
\text { district }\end{array}$ & 0.68 & 0.48 & 0.14 & 1.16 & 0.45 & 0.13 & 0.32 & 0.01 \\
\hline
\end{tabular}

* Total number of those coming from the regions of all neighbouring countries to all Hungarian counties is $100 \%$. 
Proportions of major migration flows, 2011

\begin{tabular}{|c|c|c|c|c|c|c|c|c|c|}
\hline $\begin{array}{l}\text { Foreign/ } \\
\text { Hungarian } \\
\text { counties }\end{array}$ & $\begin{array}{c}\text { Buda- } \\
\text { pest }\end{array}$ & $\begin{array}{l}\text { Bács- } \\
\text { Kiskun }\end{array}$ & $\begin{array}{l}\text { Borsod- } \\
\text { Abaúj- } \\
\text { Zemp- } \\
\text { lén }\end{array}$ & $\begin{array}{c}\text { Csong- } \\
\text { rád }\end{array}$ & $\begin{array}{l}\text { Győr- } \\
\text { Moson- } \\
\text { Sopron }\end{array}$ & $\begin{array}{l}\text { Hajdú- } \\
\text { Bihar }\end{array}$ & $\begin{array}{l}\text { Komá- } \\
\text { rom- } \\
\text { Eszter- } \\
\text { gom }\end{array}$ & Pest & $\begin{array}{c}\text { Sza- } \\
\text { bolcs- } \\
\text { Szat- } \\
\text { már- } \\
\text { Bereg }\end{array}$ \\
\hline Bacau & 0.67 & 0.04 & 00 & 0.1 & 33 & 0.02 & 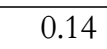 & .50 & 0.00 \\
\hline Bihor & 0.60 & 0.09 & 0.06 & 0.47 & 0.19 & 1.54 & 0.26 & 0.52 & 0.41 \\
\hline Brasov & 0.19 & 0.05 & 0.00 & 0.01 & 0.05 & 0.03 & 0.02 & 0.76 & 0.16 \\
\hline Cluj & 0.91 & 0.35 & 0.02 & 0.03 & 0.02 & 0.10 & 0.03 & 0.43 & 0.03 \\
\hline Covasna & 2.97 & 0.31 & 0.05 & 0.32 & 0.28 & 0.05 & 0.19 & 1.81 & 0.02 \\
\hline Harghita & 3.81 & 0.81 & 0.09 & 0.25 & 0.54 & 0.15 & 0.2 & 3.53 & 0.16 \\
\hline Hunedoara & 0.90 & 0.39 & 0.01 & 0.11 & 0.01 & 0.00 & 0.04 & 0.21 & 0.01 \\
\hline Mures & 4.52 & 0.70 & 0.09 & 0.73 & 0.29 & 0.17 & 0.1 & 1.57 & 0.04 \\
\hline Salaj & 1. & 0.07 & 0.03 & 0.0 & 0.04 & 0.38 & 0.0 & 0.62 & 0.06 \\
\hline Satu Mare & 1.77 & 0.19 & 0.06 & 0.11 & 0.10 & 0.40 & 0.08 & 0.85 & 0.86 \\
\hline $\begin{array}{l}\text { Banska Byst- } \\
\text { rica district }\end{array}$ & 0.55 & .01 & .12 & 0.04 & 0.31 & 0.04 & 0.06 & 0.14 & 0.01 \\
\hline Kosice district & 0.39 & 0.03 & 0.74 & 0.0 & 0.26 & 0.07 & 0.04 & 0.08 & 0.08 \\
\hline Trnava district & 0.65 & 0.01 & 0.02 & 0.01 & 0.46 & 0.06 & 0.0 & 0.14 & 0.03 \\
\hline Nitra district & 1.30 & 0.07 & 0.03 & 0.04 & 0.96 & 0.02 & 0.93 & 0.44 & 0.03 \\
\hline $\begin{array}{l}\text { Bratislava } \\
\text { district }\end{array}$ & 0.09 & 0.02 & 0.03 & 0.00 & 1.09 & 0.00 & 0.06 & 0.03 & 0.00 \\
\hline $\begin{array}{l}\text { Berehove } \\
\text { rayon }\end{array}$ & 2.68 & 0.13 & 0.12 & 0.09 & 0.11 & 0.25 & 0.10 & 0.60 & 0.94 \\
\hline $\begin{array}{l}\text { Vynohradiv } \\
\text { rayon }\end{array}$ & 0.94 & 0.09 & 0.09 & 0.01 & 0.07 & 0.21 & 0.05 & 0.49 & 0.94 \\
\hline $\begin{array}{l}\text { Uzshorod } \\
\text { rayon }\end{array}$ & 0.83 & 0.09 & 0.10 & 0.02 & 0.01 & 0.24 & 0.07 & 0.22 & 0.52 \\
\hline $\begin{array}{l}\text { Severnobacki } \\
\text { district }\end{array}$ & 1.02 & 0.75 & 0.02 & 0.75 & 0.09 & 0.01 & 0.00 & 0.26 & 0.00 \\
\hline $\begin{array}{l}\text { Severnobanat- } \\
\text { ski district }\end{array}$ & 0.66 & 0.29 & 0.04 & 1.93 & 0.07 & 0.04 & 0.03 & 0.23 & 0.02 \\
\hline Wien & 0.04 & 0.02 & 0.00 & 0.01 & 0.56 & 0.01 & 0.03 & 0.08 & 0.00 \\
\hline
\end{tabular}

The increasing attraction of the capital area is perceptible not only in the case of major emitting regions but also almost in the entire Carpathian Basin (Rédei M. 2009). This Hungarian area is unequivocally a destination for the migrants, even those coming from remote geographical destinations (Soltész B. et al. 2014). This statement is especially valid for working age migrants, those having higher education, working in leadership positions, and living in households without children. The major attraction of Central Hungary is a partial consequence of the magnitude of population and partially, in the most important way, due to its economic attractiveness: advantageous labour market and income positions. The focussed nature of flows underlines the

Regional Statistics, Vol 6, No 2. 2016: 95-113; DOI: 10.15196/RS06205 
economic motivations behind a significant portion of the migratory movements; however, the cultural and educational opportunities might have also contributed to the attractiveness of the destination. The border areas are rather considered as local destinations. In case of small geographic distances and movements near the border, the rate of those moving with their children is higher. The distance factor displays the cost and partly the risks involved in migration. In this light, it is not surprising that people that are more educated undertake or are capable of visiting distant destinations (e.g. Budapest and Pest county, which are the same in terms of labour market). However, shorter distance is less costly (shorter distance provides greater access to local knowledge), less risky, and provides easier mobility. Most likely, these reasons might contribute towards the fact that families with children prefer the short distance option. For example, this option enables them to reserve the possibility of nonmonetary transfers from the family (e.g. family assistance, contribution towards caring, and making provisions for children), which cannot be utilised due to the cost factors involved in case of greater distances. In case of near-border movements, the occupations and levels of education of the migrants are more diversified; however, the differences between the economic activity of short-distance and long-distance migrants are not significant. Therefore, the differences are not primarily in terms of employment, but in the nature of occupations. Migrants who worked in occupations that did not require educational qualifications could be found almost everywhere in the country by 2011, and such migrants gained prominence in studies focussing on cross-border relationships. In our opinion, in the case of migration among the Carpathian regions, the settlement of less skilled labour and families with children clearly underlines the special consideration given to the cost factor involved in the migration distance. The role of distance as a cost factor is markedly present in the theoretical tradition of migration. Among classical authors, Sjaastad (1962) assumed that the cost of moving is proportional to the distance of migration. Distant moves are accompanied by higher risk or significant monetary and psychic costs, while the shorter ones have the opposite effect. Therefore, it is real that families with children have preferred short-haul destinations while reserving their previous connections and networks (for example, seeking assistance from parents located across the border).

\section{Depiction of migration relations}

The most common way to display migration links is through flow charts (Tobler 2003; Daróczi-Bálint, 2015). The charts presented here-due to the one-way connectionscorrespond to the so-called 'Desire line' maps that indicate the connections of given points using straight lines. Counties across the border and those within Hungary have been identified with their geometrical centres. The lines point to the destinations of those arriving in Hungary and the connection structure of the counties across the border. For the 'readability' (transparency) of the map, the representation under 100 migrations was disregarded. The thickness of the lines and the differences in hue, similar to that applied in thematic maps, express the difference in the number of migrations.

Regional Statistics, Vol 6, No 2. 2016: 95-113; DOI: 10.15196/RS06205 
Figure 1

Area relations between source and destination regions*

2001

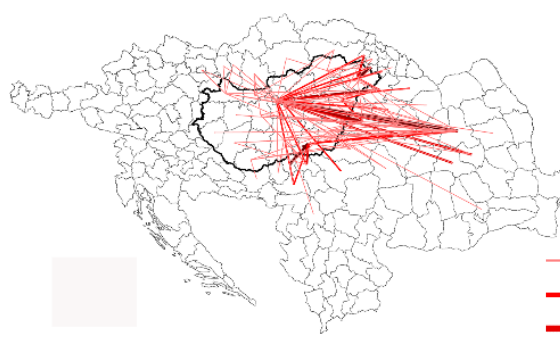

$$
\begin{array}{r}
\longrightarrow \quad 100-300 \\
\rightarrow \quad 301-600 \\
\rightarrow \quad 601-900 \\
\longrightarrow \quad 901-1,200
\end{array}
$$

* The maps illustrating the networks have been prepared with the help of QGIS software FlowMapper plugin (Güllüoğlu 2013).

Relationship between regions of the place of birth and current Hungarian residence of foreign citizens above 24 years, by education

2001

Primary

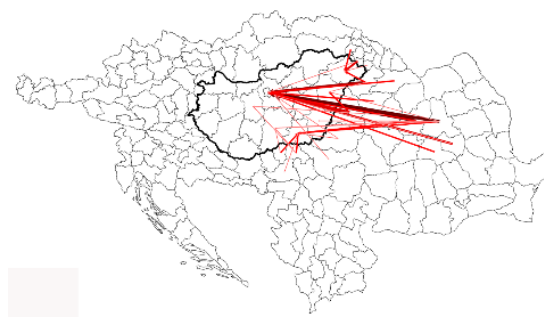

Person

- $100-150$

$\longrightarrow 151-250$

$\longrightarrow 251-350$

$\rightarrow 351-450$

$\Rightarrow 451-$

\section{1}

Primary
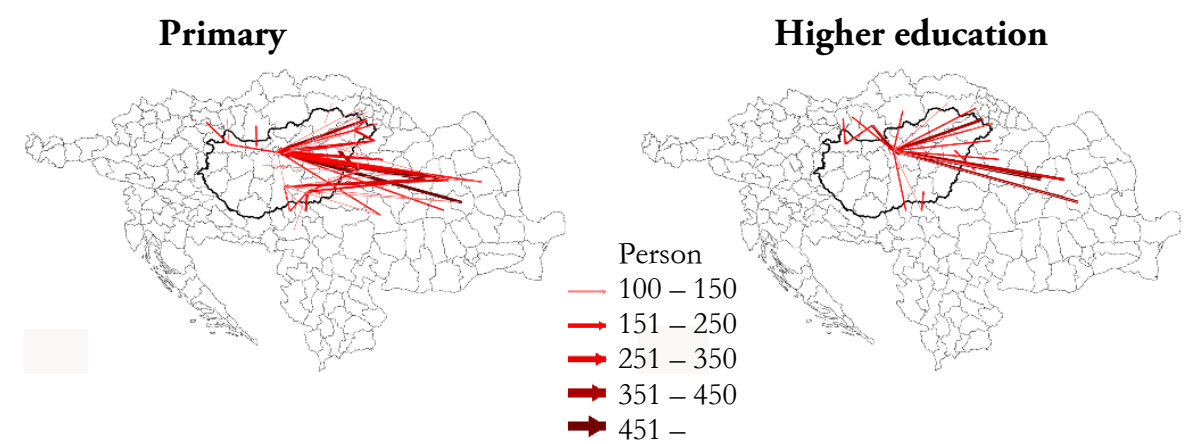

\section{Higher education}

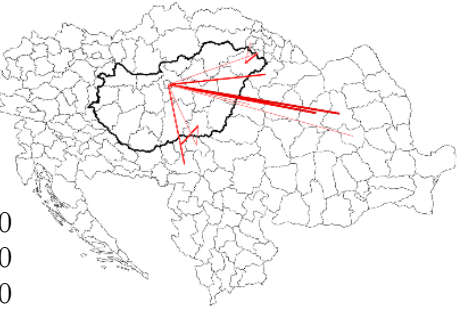

Figure 2 
Relationship between regions of the place of birth and current Hungarian residence of foreign citizens above 24 years, by type of household

2001

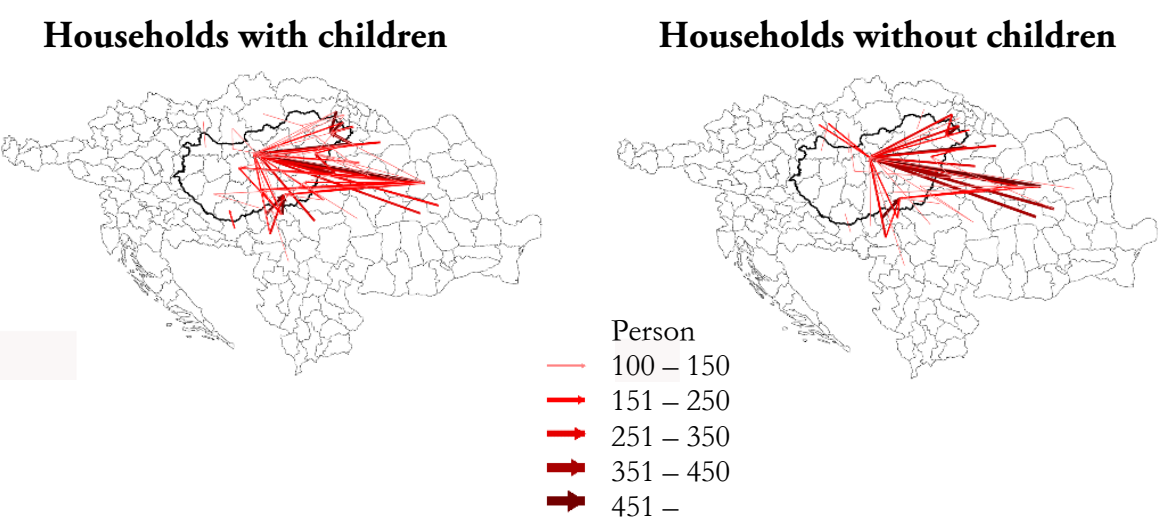

2011

Households with children

\section{Households without children}

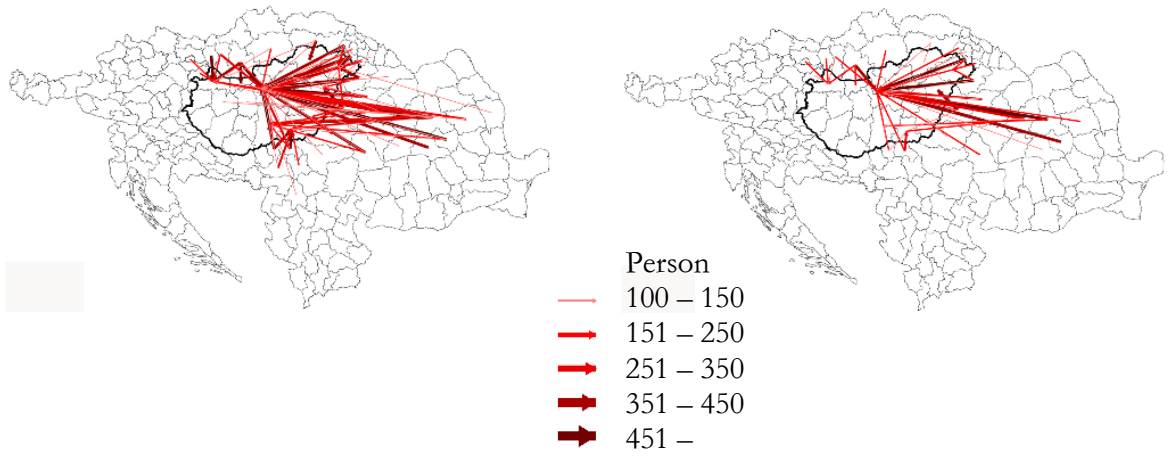


Relationship between regions of the place of birth and current Hungarian residence of foreign citizens aged 25-64 years, by economic activity

2001

Employed

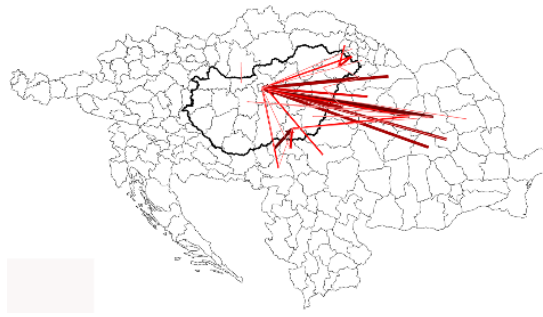

- $100-150$

$\longrightarrow \quad 151-250$

$\rightarrow 251-350$

$\rightarrow 351-450$

$\Rightarrow 451-$

2011

Employed

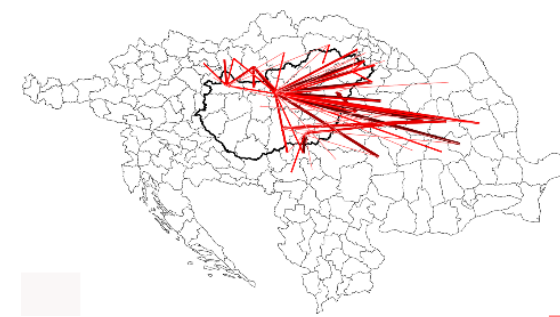

Person

- $100-150$

$\longrightarrow \quad 151-250$

$\rightarrow \quad 251-350$

$\rightarrow 351-450$

Regional Statistics, Vol 6, No 2. 2016: 95-113; DOI: 10.15196/RS06205

$\rightarrow 451-$
Person

Unemployed

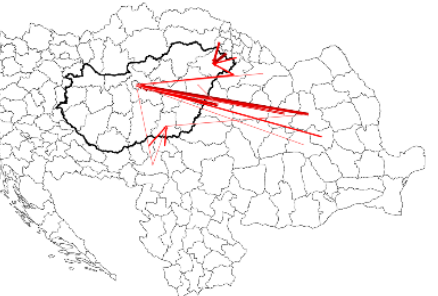

Unemployed

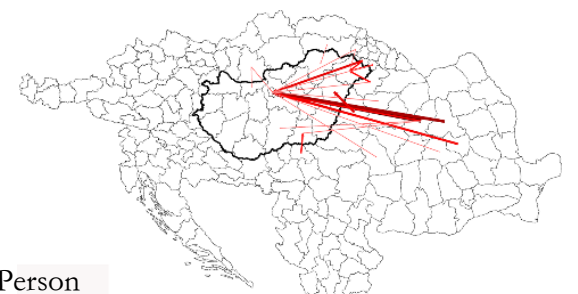


Relationship between regions of the place of birth and current Hungarian residence of foreign citizens aged 25-64 years, by occupation

2001

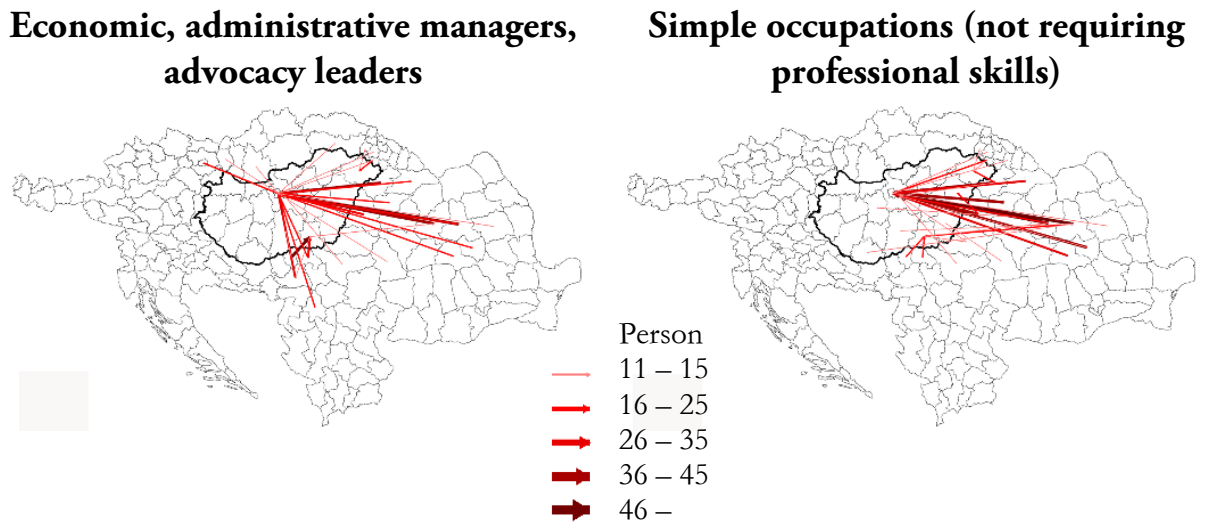

2011

Economic, administrative managers, Simple occupations (not requiring advocacy leaders professional skills)

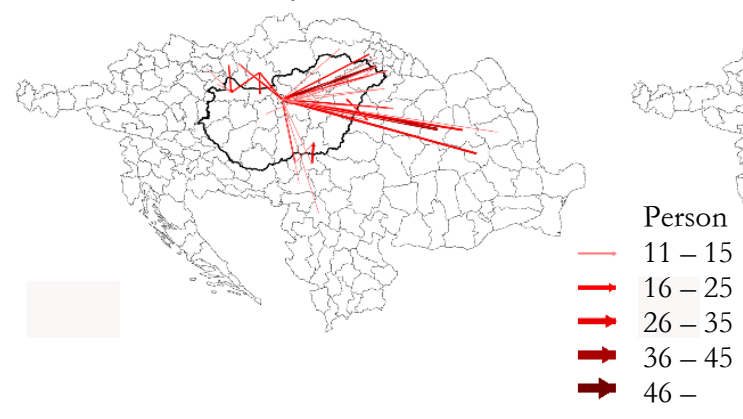

\section{Networks of migration settlements}

In the previous section, we have strived to establish the relationship between regions of the place of birth and current Hungarian residence of foreign citizens, at the NUTS3 level, arriving from neighbouring countries in Hungary and the demographic and labour market variables of migrants. Currently, we have tried to analyse in detail the internal features of the settlement networks. Network analysis started in the second half of the twentieth century (Erdős P. et al, 1959, 1960; Bollobás B. et al, 1976). One of the most interesting theses of this era representing a paradigm changing (M. Buchanan, 2003) is that any two people on earth are connected by six degrees of separation (acquaintances connection). Subsequent to these initial theses of graph theory, the network theory gained recognition as a new discipline due to its new 
abstractions. This was based on the findings, according to which every network, living or dead, existing in nature or artificial, comes into being partly according to identical organising principles. That means that the Internet, human relations, and neural network of the brain are very similar in their properties (Barabási A. L., 2008).

Degree distribution (links distribution) of random systems follows a bell curve. In other words, the majority of points have about the same number of connections and the probability of the existence of those points having large and a small number of connections is insignificant (distribution of people according to height produces this curve, and the probability of the existence of extremely tall or extremely short people is small). In general, a road network of a country-where the connections of the settlements refer to specific points and the interconnection of roads refer to the links-resembles of a random network. Precisely, the scale-free network (according to a power law), like in most networks, describes the relationships between people. Here, the degree distribution according to a power law predicts that the highest number of points (people) have only a small number of different social connections (the majority of people do not know ten thousand or hundred thousand other people in person), which is held together by some hubs facilitating large interconnections. A good example for this is the map in the bottom right of the following figure that shows the air traffic system: many small airfields can be connected by a few main hubs (Barabási A., 2008.)

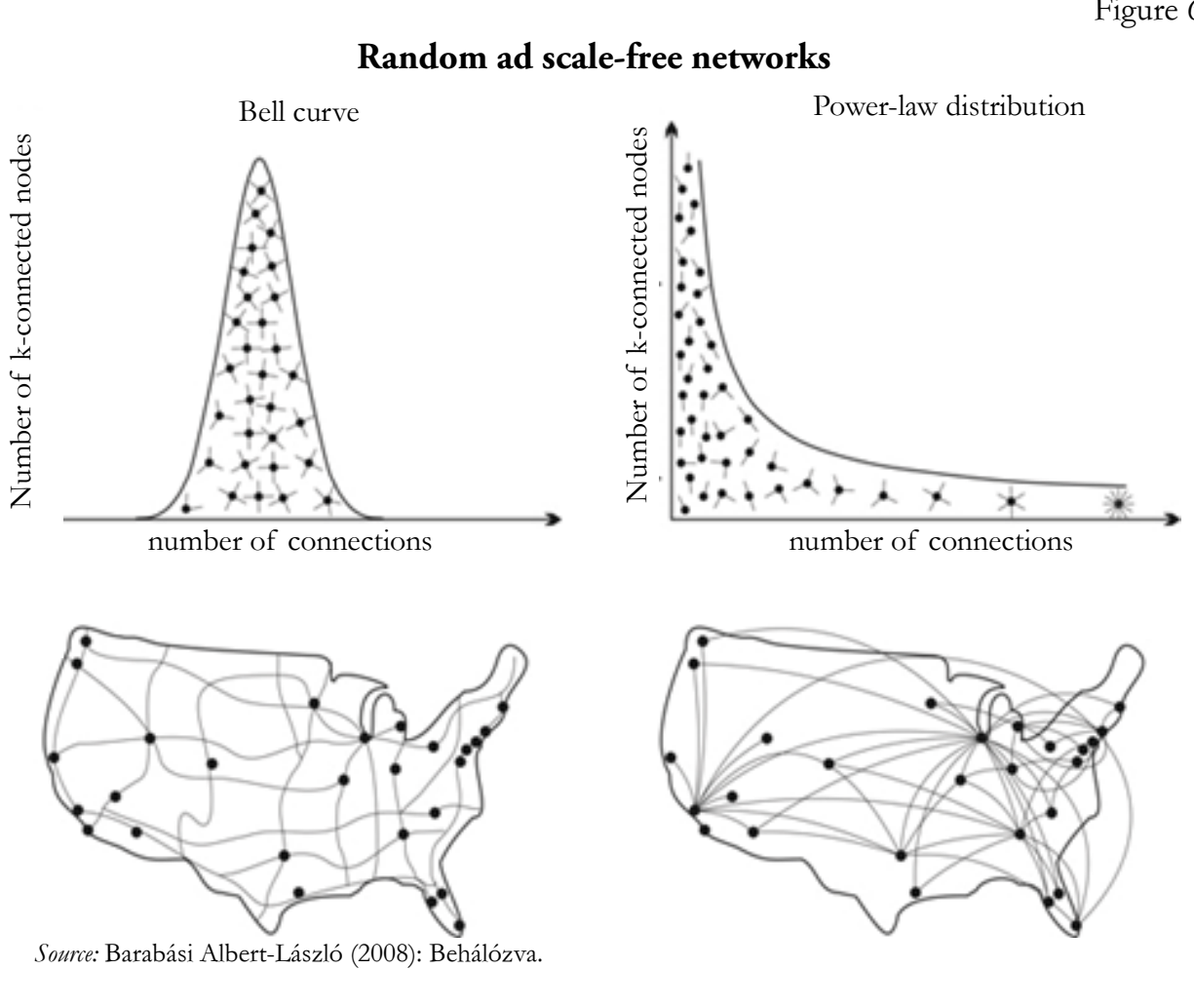

Regional Statistics, Vol 6, No 2. 2016: 95-113; DOI: 10.15196/RS06205 
For us, the network theory is important from the point of view of migration because of the links between the settlements, which is connected by international migration that is affecting Hungary. It means that the settlements are the vertices of the graph.

Two settlements are connected by an edge (they are linked) if international migration has taken place between the two settlements, i.e. someone has migrated from a settlement by moving to another (Hungarian) settlement, regardless of the number of migrants (probably personal relationship among migrants shows similar attributes, but data compilation on such personal contacts of migrants is unavailable). We consider it important to analyse the connection network of Hungarian host settlements in the Carpathian Basin because it shows the extent to which a migration is diversified and the degree of 'embeddedness' in the settlement.

On October 1, 2001 (referring to the date of the census), Budapest had the most Romanian migration connections. Romanian citizens arrived in the capital from 378 different settlements of Romania. Debrecen had the second most links (96), followed by Szeged (87), Békéscsaba (64), and Nyíregyháza (60). By 2011, Budapest further increased the number of its links (417), while Debrecen slightly relegated (69). However, e Érd (71), Szeged (87), Budaörs (48), Kecskemét (55), and Szigetszentmiklós (55) significantly strengthened the settlement links, thereby enhancing the attractiveness of Central Hungary. Degree of the nodes Békéscsaba - Gyula and Debrecen - Nyíregyháza is decreasing, and their place is taken over by the villages surrounding Szeged and Kecskemét. The network's centre of gravity has shifted to the West in the period between the two censuses, but Eastern Hungary, Budapest, and Pest County remained the two key areas.

In case of Serbia, it is also true that the capital has the settlement links of the highest degree (in 2001: 94, in 2011:109). Connectedness of Szeged (in 2001: 37, in 2011: 97) is the second largest, but more Serbian citizens (2047 people) live here than in the capital (1801 people). This means that more people arrive in Szeged from fewer Serbian settlements near the border (on an average in greater numbers by settlement), while migrants come to the capital from many places but on an average in smaller numbers. In the regional relations, a slight increase can be observed between the two censuses for Pécs (33 to 38), Kecskemét (27 to 37), and Baja (25 to 28), while Kiskunhalas (25 to 22), Hódmezővásárhely (from 22 to 14), and Röszke (from 22 to 8) show significant decreases.

In case of Ukraine, the number of links of the major cities along the Hungarian border does not increase significantly, while Budapest and several settlements of Pest County are characterised by growth. However, the order among the most connected settlements remained mostly unchanged. Thus, the following ranking is given to the settlement networks: Budapest (145 to 221), Debrecen (45 to 76), Nyíregyháza (46 to 65), Kisvárda (40 to 38).

Regional Statistics, Vol 6, No 2. 2016: 95-113; DOI: 10.15196/RS06205 
Number of relationships between migration settlement networks in Carpathian Basin

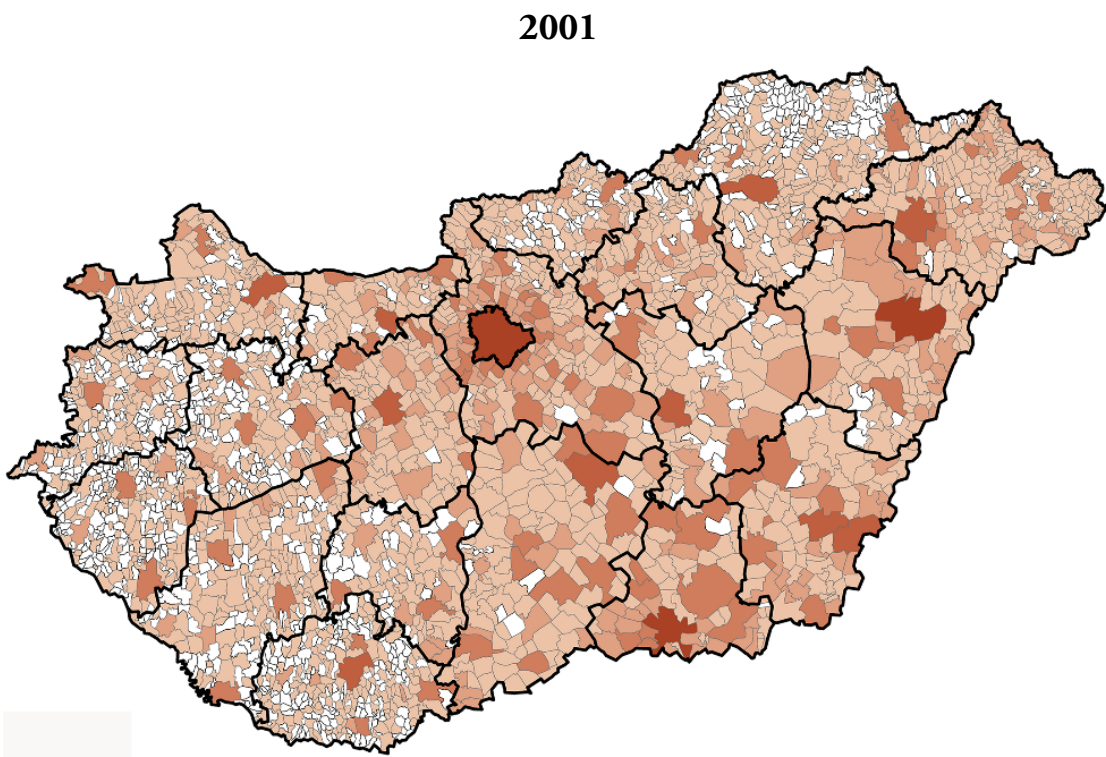

2011

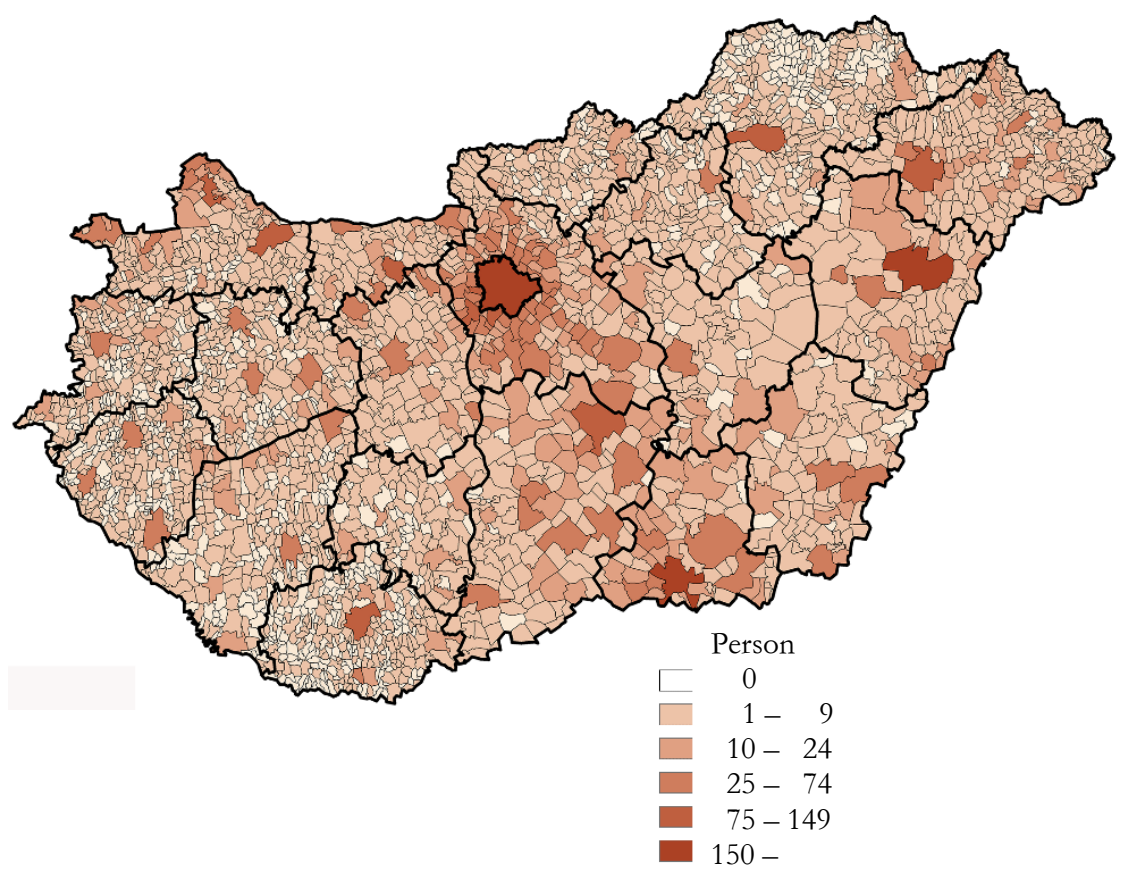

Regional Statistics, Vol 6, No 2. 2016: 95-113; DOI: 10.15196/RS06205 
Other neighbouring countries do not facilitate much connectedness among the settlements (and migrants) in Hungary. Here, the capital's growing dominance can be observed. In case of Slovakia, the links with Érd (4 to 71) and Budapest (64 to 106) developed in the most dynamic way in 2011. Besides Györ (13 to 37), the connectedness of Miskolc (from 16 to 28), Esztergom (13 to 22), and Komárom (16 to 26) registered an increase. As for the Austrian settlements, they have the most pronounced connections with Budapest (growth: 31 to 164). In addition, the dynamics of Mosonmagyaróvár (7 to 43), Kaposvár (1 to 23), Lenti (3 to 18), Győr (5 to 13), Hegyeshalom (3 to 21), and Fertőd (1 to 21) worth mentioning. Croatia's migration settlement links with Budapest (28 to 34), Györ (1 to 17), and Harkány (9 to 16) have been intensified, while those of Pécs (24 to 14), Mohács (20 to 2), Baja (12 to 2) and Siklós (22 to 9) decreased, i.e. the nearby settlements have lost their network strength. Although Slovenian citizens in Budapest came from eight different settlements, the number of Slovenian citizens in Hungary is minimal. The examination of Hungarian migratory connections in relation to the settlements of all the neighbouring countries reveals that the central role of Budapest and Pest county in strengthening the connections is indisputable.

Overall, the regions of Central Hungary dynamically increase the number of migration settlements connections, while major border cities lose connectedness. People arrived in Budapest from 744 different settlements of neighbouring countries on 1 October 2001, whose number increased to 1059 by 2011. Dynamically developing settlements migration networks are characteristic along the axes of Dunakeszi, Fót, Göd, Vác, Szentendre, Pomáz, Budakalász, and Solymár; and Pécel, Maglód, Kerepes, and Gödöllő, with both set of regions starting from Budapest. Linear developments can be witnessed in the major sending countries, while on the western side of the capital a block-like growing structure can be seen with regard to two separate sets of regions: Ülló, Vecsés, Gyál, Monor, Pilis, Cegléd and Érd, Tárnok, Biatorbágy, Budaörs, Törökbálint, Budakeszi, and Szigetszentmiklós.

Examining the degrees (connections) of migration settlement networks, besides Budapest, the migratory links of settlements with neighbouring countries comprising Szeged, Debrecen, Pécs, Kecskemét, Győr, Nyíregyháza, Mosonmagyaróvár, Érd, Miskolc, Szigetszentmiklós, Budaörs, Tatabánya, Rajka, Cegléd, Székesfehérvár, Vecsés, Szentendre, Dunakeszi, Fót, and Vác, the large cities and the settlements close to Budapest, are significant. Connections of the agglomeration of Budapest and those of Szeged, Győr, and Kecskemét increased during the sampled ten years, while the stagnation or decline in the number of connections is typical for the other major towns. Settlement links and dynamics imply the regional changes in the volume of future migrations. The degree is likely to decrease in cases when the sender areas have exhausted or the host areas have saturated and the previous migration flows have declined. In addition, the attractiveness of other areas might influence the choice of new migrants.

Regional Statistics, Vol 6, No 2. 2016: 95-113; DOI: 10.15196/RS06205 
After determining all Hungarian settlements by the degrees, i.e. the number of different settlements of neighbouring countries they had through the international migration, we examined the number of Hungarian settlements disposed of the given degree. The question is whether a random, a scale-free, or another topology will be explored. The results are shown in the case of Romania as of 1 October 2011. Having the given link according to the logarithm of the number of connections, the logarithm of the number of settlements was depicted. The result shows that the closer the graph is to the line, the truer it is that the migration settlement network has power law distribution.

\section{Degree distribution of settlements affected in Romanian-Hungarian migration, 2011}

Figure 8

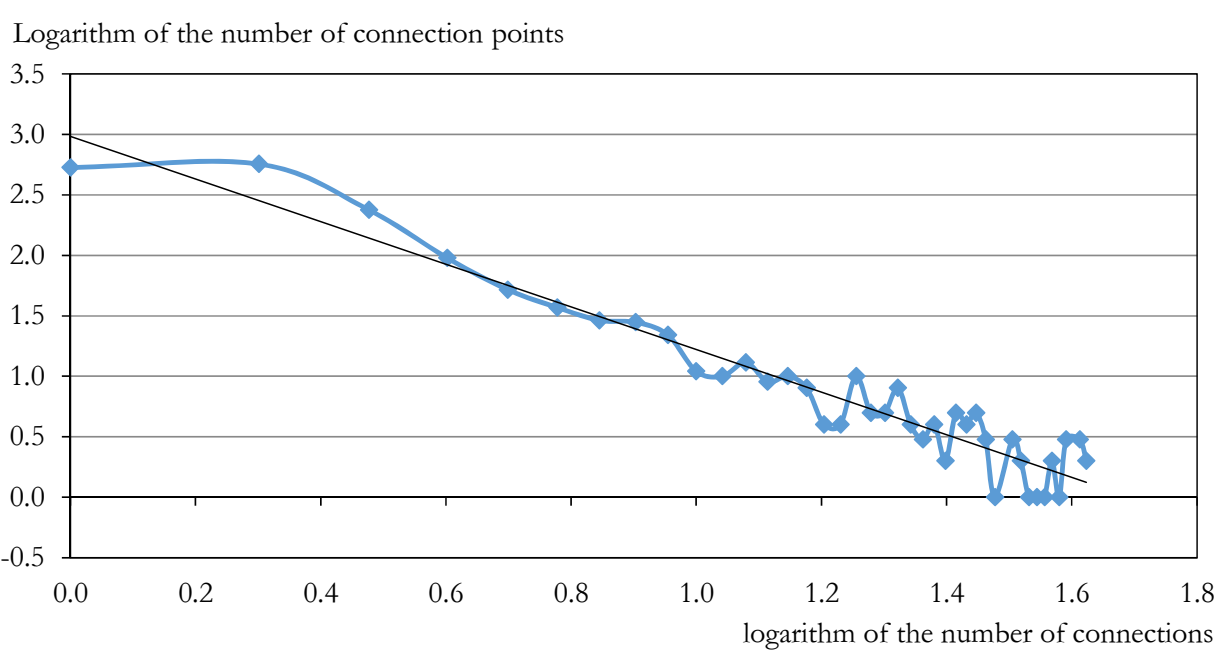

Most Hungarian settlements have a few connections with Romanian ones through the migration (there are many points of small degrees), while there are a few settlements that have several links. Amount of Hungarian settlements having the given link by the number of connections according to a power law is $\left(\mathrm{R}^{2} \approx 0,86\right)$. It can be concluded that the Hungarian migration settlement connections from Romania towards Hungary show a scale-free topology. It is not only met in the case of Romania, but also for all the neighbouring countries, individually and together as well. The $\mathrm{R}^{2}$ values that measure the accuracy of fit are mentioned in the following table. 
Fit of degree distributions of migration settlements to the scale-free topology by citizenship (R2)

\begin{tabular}{l|l|l}
\hline \multicolumn{1}{c|}{ Citizenship } & 2001 & 2011 \\
\hline Romania & 0.862 & 0.856 \\
Serbia & 0.846 & 0.687 \\
Ukraine & 0.827 & 0.788 \\
Slovakia & 0.722 & 0.905 \\
Austria & 0.714 & 0.700 \\
Croatia & 0.777 & 0.726 \\
Slovenia & 0.985 & 0.900 \\
\hline
\end{tabular}

Our results confirm that the network of Hungarian settlements affected by the migration clearly shows a scale-free topology (Kincses Á., 2012). Scale-free topology is the direct consequence of the expanding nature of real networks (Barabási A., 2008). A network exhibits scale-free topology because of its number of connections - settlements with more connections will be far more attractive for the migrants than those having a lesser degree (1). According to the theory of migration networks (Sandu D., 2000; Kis, T., 2007), integration into a new environment is successfully carried out when it is aided by former family and friends. Following the 'beaten path' of emigration involves establishing contacts with previous immigrants, which also has a significant impact on the subsequent migration decisions (Rédei M., 2005). This is underpinned by the fact that one of the main 'tracks' of access to a certain country involves family reunification in most countries even today. Several newcomers also settle down with their kin and acquaintances.

Therefore, migration is more 'embedded' into a settlement with more links. In addition, greater potential migrant populations can be absorbed into a network by tapping the social and family circle of the migrants. A migrant is likely to choose a popular settlement with many connections, about which more information is available, rather than an unfamiliar settlement. Thus, the direction and magnitude of migration are affected the most by the appearance of migration networks in addition to income inequalities and migration distances. However, it is also visible that the settlements of greater degrees are generally larger in size, which may also be related to labour market positions. The size of target areas is cardinal because of the gravitational nature of migration. Relationship by distance and education indicates clearly that network mechanisms do not necessarily prevail. 


\section{Summary}

In our study, the connections between the place of residence of birth and current dwelling of foreign citizens coming to Hungary from neighbouring countries were examined in detail. An examination of the connection system indicates the regions that have emerged stronger and those with weaker functional connections (Bell et al., 2003). In addition, depiction of migrations by socio-demographic groups offers more opportunities for understanding differentiated motivations. In general, we can state that the proportion of less-qualified, migrants with children, and unqualified migrants preferring short-distance migration is high, while for longer distances those with higher education become dominant. The potential impact area of migration grows in line with the education and qualification of migrants.

The Hungarian settlement connections of the migration from the neighbouring countries towards Hungary show a scale-free topology. A network exhibits scale-free topology because of its number of connections-settlements with more connections will be far more attractive for the migrants than those having a lesser degree. Greater potential migrant populations can be absorbed into a network by tapping the social and family circle of the migrants. A migrant is likely to choose a popular settlement with many connections, about which more information is available, rather than an unfamiliar settlement. The reasons why the Hungarian settlements are linked more strongly to the network are not random. In development, the build-up of networks causality is an important explanatory factor. If immigrants can find work, higher income, and better living conditions in a settlement, compared to other settlements, the higher standard of living creates a certain attraction; this establishes a pull-effect, and the established networks continue to reinforce this attraction. This implies that most Hungarian settlements have few links from neighbouring countries by migration (there are many points of small degree), while few settlements have many connections. The finding also means that, subsidiarity and regional strategies can play a decisive role, instead of the national migration strategy, in the management of the international migration process.

\section{Acknowledgement}

The Bolyai Research Scholarship has supported this study.

\section{REFERENCES}

Anderson, J. - O’Down, L. (1999): Borders, Border Regions and Territoriality: Contradictory Meaning, Changing Significance Regional Studies 33 (7): 593-604.

BARANYI, B. - BALCSÓK, I. (2004): Határ menti együttmüködés és foglalkoztatás - Kelet-magyarországi belyzetkép In: Múhelytanulmányok 2004/20, MTA Közgazdaságtudományi Intézet, Budapest.

Regional Statistics, Vol 6, No 2. 2016: 95-113; DOI: 10.15196/RS06205 
Bollobás, B. - Erdős, P. (1976): Cliques in Random Graphs Math. Proc. Cambridge Phil. Soc. 80 (3): 419-427.

Buchanan, M. (2003): Nexus, avagy kicsi a világ Typotex, Budapest.

BarabÁSI-Albert, L. (2008): Behálózva Helikon Kiadó, Budapest.

Bell, M. - Blake, M. - Boyle, P. - Duke-Williams, O. - Rees, P. - Stillwell, J - - Hugo, G. (2002): Cross-National Comparison of Internal Migration: Issues and Measures Journal of the Royal Statistical Society. Series A (Statistics in Society) 165 (3): 435-465.

GÜLLÜOĞLU, C. (2013) FlowMapper v0.4 https://plugins.qgis.org/plugins/FlowMapper/version/0.4/

DARÓCZI, G. - BÁlint, L. (2015): Áramlástérkép R-ben Területi Statisztika 55 (4): 339-355.

ERDős, P. - RÉNYI, A. (1959): On Random Graphs. I. Publicationes Mathematicae 6: 290-297.

ERdős, P. - RÉNYI, A. (1960): On The Evolution of Random Graphs Magyar Tudományos Akadémia Mat. Kutató Int. Közl. 5 (1-2): 17-61.

Estélyi, K. - Keszegh, B. - KovÁCs, P. - MikóCZy, I. (2006): Munkaerőmozgás a szlovákmagyar határ mentén Fórum Társadalomtudományi Kutató Sz̧emle 8 (1): 25-48.

FErcsiK, R. (2008): Szülőföldről a hazába - és vissza? In: Szarka, L. - Kötél, E. (szerk.): Határbelyzetek. Külhoni magyar egyetemisták peregrinus stratégiái a 21. század elején pp. 124-138., Balassi Intézet Márton Áron Szakkollégium, Budapest.

HANSEN, N. (1977): Border Regions: a Critique of Spatial Theory and an European Case Studies Annals of Regional Science 11 (1): 1-12.

ILLÉS, S. - KINCSES, Á. (2009): Cirkuláció és migráció Magyarország nemzetközi vándormozgalmában Statisz̧tikai Szemle 87 (7-8): 729-747.

KINCSES, Á. (2012): A Kárpát-medence eqredforduló utáni migrációs hálózatának viqsgálata Központi Statisztikai Hivatal, Budapest.

KIS, T. (2007): Demográfiai modellek és a migráció Régió 18 (2): 160-189.

MelegH, A. L. (2011): Globalizáció és migráció Magyarországon Educatio 20 (2): 206-219.

RÉDEI, M. (2005): A nemzetközi vándorlás folyamatának irányítása Statisz̨itkai Szemle 83 (7): 662-680.

RÉDEI, M. (2007): Mozgásban a világ, a nemzetközi migráció földrajza Eötvös Kiadó, Budapest.

RÉDEI, M. (2009): Foreigners in Budapest Hungarian Statistical Review 13 (87): 31-49.

SOltÉSZ, B. - ERŐSS, Á. - KARÁCSONYI, D. - KINCSES, Á. (2014): Hungary: cross border migration in a fragmented ethnic space In: ERŐss, Á. - KARÁCSONYI, D. (eds): Discovering migration between Visegrad countries and Eastern Partners pp. 7287., Geographical Institute, Research Centre for Astronomy and Earth Sciences of the Hungarian Academy of Sciences, Budapest.

SANDU, D. (2000): Migraţia transnaţională a românilor din perspectiva unui recensământ comunitar Sociologia Romaneasca 3-4: 5-52.

SjaAstad, L. A. (1962): The Costs and returns of Human Migration The Journak of Political Economy 70 (5): 80-93.

Regional Statistics, Vol 6, No 2. 2016: 95-113; DOI: 10.15196/RS06205 
TOBLER, W. (2003): Movement Mapping (unpublished paper)

http://csiss.ncgia.ucsb.edu/clearinghouse/FlowMapper/MovementMapping.pdf (letöltve: 2015. január)

TOBLER, W. (2012): Looking at Some Data from Isard's "Methods of Regional Analysis" Regional Statistics 2: 3-12.

TótH, G. (2013): Bevez̨etés a területi elemzések módszertanába Miskolci Egyetemi Kiadó, Miskolc. VAn Geenhuizen, M. - RatTi, R (2001): Gaining Advantage from Open Borders. An active Space for Regional Development Ashgate, Aldershot. 